\title{
A Second Lefier to an Imaginary Soviet Scientist
}

DeAR Colleague-Your kind invitation to attend the International Conference in Moscow this summer arrived this morning, and I hasten to reply. The programme is unusually interesting. Yet I am not quite sure whether I shall, in fact, accept the invitation. Something troubles me, and I need your advice as an old friend and colleague.

Let me say, first of all, that I have long wished to visit the Soviet Union, not only for its tourist attractions but in order to make closer contact with Soviet scientists in our field. In an earlier letter (Nature, 217, 123 ; 1968) I remarked on some of the confusions that arise when arrangements are made for Soviet scientists to attend conferences in other countries. If you cannot easily come to us, then we should make special efforts to attend conferences and visit laboratories in the Soviet Union so as to keep each other well informed on our scientific progress.

In particular, I was looking forward to a long visit to your theoretical group, whose head has done such brilliant and exciting work over the last ten years. Imagine my distress, then, to see his name in the newspaper, and to receive from him, by a roundabout route, a heart. rending plea for help and support in terrible circumstances. You know much more about it than I do, for it must have hit you particularly hard that your young colleague, with whom you have worked so closely over so many years, should be dismissed from his post, and from all scientific work, for daring merely to ask that he might be allowed to emigrate to Israel. You and I as scientists, can feel the additional cruelty of the order that his books-the fruits of half a lifetime of effort-should be withdrawn from the libraries and that his papers should not be cited in future.

I understand perfectly that there is very little that you and your colleagues can do in the face of such forces. No doubt you are helping our friend in private, with the gifts and sympathy so characteristic of Soviet intellectuals. I suspect that you will also devise ways by which he can continue to do research in private and will be sure to keep his name in the scientific literature: no scientist who is remotely capable of judging the relevance of a citation would be an accomplice to this utter perversion of the system on which we all depend for our scholarly recognition.

If Soviet scientists are to be denied the fruits of their honest labours, then Soviet science will soon be at the mercy of dishonest timeservers. You must be trembling inwardly with the thought that a higher patriotism than complete obedience to these orders would be to preserve for the Soviet Union the sceptical, critical, imaginative scientific way of life.

But my real question to you is - what should we do: what should I do, to help the scientific friend whom I have never met? I do not think I am greatly influenced in this by my own Jewish birth and upbringing, which in a free society I need neither exalt nor repudiate. A man in trouble has called on me by name, invoking the universalism of science, and the fellowship of our Invisible College, which knows no natural frontiers: I must surely heed his call.

One form of help is very easy to get in this case-publicity. All normal procedures of protest are being actively pursued, in the press, in government circles, through embassies, and so on. It is scarcely to be believed that much more can now be accomplished in this way.

Can anything be done through our scientific organizations and learned societies? It is my belief that this particular case-like a number of other cases in various countries (e.g. in recent years, Argentina and Czechoslovakia)constitutes such an infringement of the norms of the scientific community that it is our duty to take notice of it officially. It seems to me, for example, that the agreements made between the Royal Society and the Soviet Academy of Sciences for scientific exchanges are based upon the assumption that these bodies have a similar respect for scholarly integrity, for scientific authority, and for the acknowledgment of scientific originality and priority. It would not, I believe, be a transgression of its principle of avoiding "politics" if the Royal Society were to question the official attitude of the Soviet Academy to these matters, and to indicate its unwillingness to cooperate with an organization that so openly failed to live up to the high ideals that we all profess to hold.

In the end, however, only a personal gesture is likely to be possible. That is why I am troubled about whether or not to accept your invitation to the Moscow conference. Should I refuse to take part myself in an activity sponsored by a government whose policy I detest, under the auspices of an organization-the Soviet Academy-whose hypocrisy I deplore? I realize that such action is largely symbolic. At some cost to myself (for it really would be pleasant and scientifically profitable to come) I cause a little damage to those whom I wish to influence and fail in my friendly duty to people, like yourself, whom I like and trust. Yet I think that the gesture is not quite useless, and that if it were copied by the many hundreds of British, European and American scientists who have been invited to scientific conferences in the Soviet Union this summer it might bring out very clearly the extent to which, as a community, we are united in detestation of these present actions by your government.

Tell me, then, colleague and friend, what I should do. I have never agreed with those who demand a boycott on visits to this or that country-Spain, Greece, South Africa, Czechoslovakiaon ger eral political grounds. A scientific visit may look like support for the policy of the government in power: but in reality, it may be valuable moral backing for those men of integrity and good will who are struggling to establish scientific standards under very adverse circumstances. I prefer to put my trust in such men, and to accept their personal invitations in the name of scientific fellowship.

Is this what you had in mind when you sent me this invitation? Would I come as an official guest of your government, expected to speak in admiration of your scientific achievements and never to express, even in private, my inner feelings on this tragedy? Or do you ask me as a personal scientific friend, not only to discuss our common interest in certain technical questions of scientific research, but also to share our common concern for what is being done to another friend by this cruel world in which we all have to live? I am not speaking, of course, of reckless public acts of defiance, or any other such extravagant, useless gestures: merely of the spirit with which you would yourself meet me on this occasion. Until I know that, allow me to reserve my reply. I hope that you will still want me to come ; but I shall understand, and admire, a message to the contrary.

Yours sincerely, JOHN ZIMAN

H. H. Wills Physics Laboratory, University of Bristol 